\title{
ORGANIZING SOLIKAMSK COACH STATION AND COACHMAN SERVICE IN GREAT PERM IN $1607^{1}$
}

\author{
Natalia V. Rybalko \\ Volgograd State University, Volgograd, Russian Federation
}

\begin{abstract}
Introduction. The city of Solikamsk on the territory of Great Perm was located on the first land road from Moscow to Siberia. This road was built in the late $16^{\text {th }}$ century. The research is devoted to the problem of establishing a permanent coachman service in Solikamsk in 1607. Methods and materials. This issue has not been studied yet. The article is based on documents from Fund no. 21 "Solikamsk Acts" (Archive of St. Petersburg Institute of History of the Russian Academy of Sciences): monarch's decrees, letters from Permian clerks, petitions. We have reconstructed the Solikamsk archive using the method of mutual compliance of documents and their source study analysis. Analysis. In the course of the study we were able to restore the chronology of events, find out the coachman service form of organization, material support, service operation conditions, staff of the Vyatka coach station by name. The paper reveals the mechanisms of managing Great Perm territory, the ways of solving problems of management and transportation. Results. The article reveals the duality of the situation in Great Perm in the early $17^{\text {th }}$ century. On the one hand, we can see functioning of a strictly centralized management system, on the other hand, we observe a strong local government in provinces. Perm's clerk Prince S.Yu. Vyazemsky had to clearly execute the orders of Moscow and was prevented from making his own decisions. At the same time, key financial issues influencing stable work of coachman service were not originally planned in Moscow. Decisions arrived late. The central government was more concerned with the timely dispatch of tax collections to Moscow. After Solikamsk coach station coachmen dissolution, the problem of transportation on the Siberian road remained.

Key words: coachman service, Solikamsk, Great Perm, Siberian road, Babinovskaya road, the Time of Troubles, Price Semen Yu. Vyazemsky, local government.

Citation. Rybalko N.V. Organizing Solikamsk Coach Station and Coachman Service in Great Perm in 1607.Vestnik Volgogradskogo gosudarstvennogo universiteta. Seriya 4, Istoriya. Regionovedenie. Mezhdunarodnye otnosheniya [Science Journal of Volgograd State University. History. Area Studies. International Relations], 2019, vol. 24, no. 2, pp. 120-136. (in Russian). DOI: https://doi.org/10.15688/jvolsu4.2019.2.11
\end{abstract}

\section{ОРГАНИЗАЦИЯ СОЛИКАМСКОГО ЯМА И ЯМСКОЙ СЛУЖБЫ В ПЕРМИ ВЕЛИКОЙ В 1607 ГОДУ 1}

\author{
Наталия Владимировна Рыбалко \\ Волгоградский государственный университет, г. Волгоград, Российская Федерация
}

\footnotetext{
Аннотация. Введение. Соль Камская территории Перми Великой была расположена на первой сухопутной дороге из Москвы в Сибирь, построенной в конце XVI века. Данное исследование посвящено проблеме 궁 функционирования ямской службы и устройства в Соли Камской яма, который просуществовал всего 1 год. ضे Особое внимание уделено вопросу управления территорией Перми Великой, механизму реализации управленческих решений из центра в разгар социально-экономического и политического кризиса Смутного времени. Методы и материаль. Данный вопрос специального изучения в исторической литературе до настоящего времени не имел. В основе исследования лежат документы из фонда № 21 «Соликамские акты» (Архив СанктПетербургского института истории РАН): царские указные грамоты, отписки пермских приказных людей, чело-
} 
битные. Проведена реконструкция Соликамского архива методом взаимного соответствия документов и их источниковедческий анализ. Анализ. В ходе исследования удалось восстановить хронологию событий, выяснить форму организации ямской службы, материальное обеспечение, условия функционирования, установить поименный состав вятских ямщиков. Выявлены механизмы управления территорией Перми Великой, способы решения проблем управления и перевозок. Результаты. Выявлена двойственность сложившейся ситуации. С одной стороны, мы видим функционирование строго централизованной системы управления, с другой стороны, наблюдаем проявления сильной земской власти на местах. Пермский приказный человек князь С.Ю. Вяземский был поставлен в жесткие рамки: он должен был четко исполнять распоряжения Москвы и был лишен возможности принимать собственные решения. В то же время ключевые финансовые вопросы, которые обеспечивали бы яму стабильную, бесперебойную работу, в Новгородской четверти изначально продуманы не были. Решения поступали с опозданием. Центральную власть больше заботила своевременная отправка налоговых сборов в Москву. После роспуска ямщиков Соликамского яма проблема перевозок по Сибирской дороге осталась.

Ключевые слова: ямская служба, Соль Камская, Пермь Великая, Сибирская дорога, Бабиновская дорога, Смутное время, князь Семен Юрьевич Вяземский, местное управление.

Цитирование. Рыбалко Н. В. Организация Соликамского яма и ямской службы в Перми Великой в 1607 году // Вестник Волгоградского государственного университета. Серия 4, История. Регионоведение. Международные отношения. - 2019. - Т. 24, № 2. - С. 120-136. - DOI: https://doi.org/10.15688/jvolsu4.2019.2.11

Введение. В конце XVI - начале XVII в. в России проводилась активная работа по хозяйственному освоению территории Перми Великой и Западной Сибири, в ходе которой главное место занимала организация и строительство путей сообщения. От длинного водного пути, носившего сезонный характер, переходили к прокладыванию сухопутных дорог, и, ориентировочно в 1595-1597 гг., от Соли Камской до верховьев р. Туры (а с 1598 г. до Верхотурья) был проложен участок «государевой Сибирской дороги».

Это была первая сухопутная дорога в Сибирь через Уральские горы, известная в истории как Бабиновская ${ }^{2}$. От начального периода существования этой дороги сохранились две царские грамоты 1599 и 1617 гг., введенные в научный оборот Г.Ф. Миллером [10, c. 305] и привлекаемые всеми исследователями, чьи труды посвящены истории Пермского края и Сибири ${ }^{3}[3$, c.102-106; 5, с. 176177 ; 6 , с. $158 ; 7$, с. $85-86,171 ; 12$, с. $111-112$; $32 ; 35$, с. $64 ; 39$, с. 16; 40; и др.]. Эти грамоты дают возможность получить общее представление о дороге: Артемий Бабинов, 2 целовальника и 40 посошных людей были посланы «новые Сибирские дороги чистить и мостов мостить», длина дороги от Соли Камской до Верхотурья составляла 263 версты, «через речки, и через бояраки, и через грязные места» построили «7 поперечных мостов»и «30 длинных». В конечном итоге за строительство этого пути и в последующем 700 верст от Верхотурья до Тюмени «вож» Артемий Бабинов получил от государя землю «безоброчно» [10, № 29, с. 378-380; № 93, с. 449-450]. В последнее время внимание к изучению истории Бабиновской дороги в Пермском крае возросло [4]. Однако информации об организации ямской службы и перевозок на раннем этапе функционирования дороги сохранилось крайне мало. Вместе с тем важным вопросом является выяснение механизма управления отдаленной территорией Перми Великой на этапе интеграции Сибири в разгар социально-экономического и политического кризиса Смутного времени.

Методы и материалы. Вопрос об организации ямской службы в Соли Камской в начале XVII в. одним из первых затронул А.С. Лаппо-Данилевский, изучая налоговую систему Московского государства XVII в. в целом. Ученый выделил две разновидности ямской службы в России: 1) ямская повинность, отбываемая всем населением без устройства яма, когда подвода снаряжалась по необходимости; 2) устройство яма с заранее выбранными ямщиками - и привел 10 городов, включая Соль Камскую, где существовала первая из вышеперечисленных форм [9, с. 366]. И.Я. Гурлянд назвал эти разновидности «мирская» и «стройная» гоньбы и расширил список городов, указав также расположенные неподалеку от Соли Камской Чердынь, Кайгородок, Вятку [5, с. 277]. Работа И.Я. Гурлянда до настоящего времени остается наи- 


\section{ИСТОРИЯ СМУТНОГО ВРЕМЕНИ}

более обстоятельным исследованием системы ямской службы в России. Ученый затронул также сюжет об устройстве яма в Соли Камской в 1607 г., отметив, что данный факт был редким исключением для этой территории ${ }^{4}[5$, с. $273-274,277]$.

В настоящее время истории дорог в Сибири и Приуралье уделяется все больше внимания. Так, специальное монографическое исследование, посвященное Московско-Сибирской дороге конца XVI - XIX в., выполнено О.Н. Катионовым, где дан обзор обширной дореволюционной и советской историографии [7, с. 14-61]. Серия статей о сибирских дорогах XVII в. опубликована О.В. Семеновым [33; 34; 36], обзор этапов функционирования Сибирской дороги от Кайгородка до Соли Камской выполнен Ю.К. Николаевым [11], отдельные аспекты воеводского управления в Приуралье изучены А.А. Космовской [8; и др.]. Однако об устройстве яма в Соли Камской в 1607 г. только упоминается [8, с. $185 ; 35$, с. 174$]$.

Документы из фонда № 21 «Соликамские акты» (Архив Санкт-Петербургского института истории РАН) дают нам возможность узнать причины, обстоятельства, итоги попытки устроить в 1607 г. постоянный ям в Соли Камской - опорном пункте новой Сибирской дороги. Это царские указные грамоты в Пермь Великую и на Вятку, черновые отпуски пермских приказных людей, челобитные, поступавшие на имя царя в Москву от пермичей и вятчан, именные росписи ямщиков.

Документы были изучены путем сплошного просмотра единиц фонда. Реконструкция Соликамского архива осуществлена методом взаимного соответствия документов. Выявлена информация о несохранившихся документах, проведена уточняющая работа по датировке и атрибуции имеющихся и утраченных документов, восстановлена перепутанная в XIX в. нумерация листов и выполнено соединение отдельных частей документов, числившихся разными единицами хранения [31]. $\mathrm{Pa}-$ бота с данным комплексом осложнялась наличием большого количества черновиков.

Анализ. Организация ямской службы входила в сферу должностных обязанностей местной администрации. Главным учреждением сферы управления в Перми Великой в начале XVII в. была приказная изба. До конца 1608 г., пока военные события гражданской войны напрямую не коснулись Пермского края, во главе ее стоял ни воевода, ни дьяк, а приказный человек, который назначался из Москвы сроком на 1-2 года и административно напрямую подчинялся дьякам Новгородского четвертного приказа. Дьяки приказа реализовывали управленческие решения из Москвы от имени государя как территориальное ведомство. Вместе с приказным человеком управление осуществлял подьячий. Вся распорядительная корреспонденция поступала на оба их имени.

В 1606-1607 гг. в приказной избе Перми Великой (в Чердыни) служили князь Семен Юрьевич Вяземский и подьячий Иван Федоров. Именно в их период управления приходилось решать сложные задачи по развитию ямской службы на Сибирской дороге.

Вопрос о необходимости развития дорог и организации ямской службы был напрямую связан с экономическими проблемами, возникшими в Перми Великой накануне Смуты. С 1582 г., с «сибирского взятия», «пермские денежные доходы, дань и оброк, и присудные, и таможенные, и кабацкие деньги» оставались в Перми «для сибирских отпусков». В 15991600 г. царь Борис Годунов приказал все доходы отправлять в Москву. Вместе с тем были сохранены и «сибирские отпуски», которые тратились на материальное обеспечение «служивых людей», организацию дальних перегонов, поддержание проходимости Сибирской дороги на Верхотурье: строительство мостов, расчистку, разбор завалов скопившихся деревьев осенью, на оплату подвод и труда летних гребцов. В годы, когда происходила «перемена воеводам и головам или прибавка служилым людям», организовывались дополнительные подводы и вместо пяти тысяч рублей расходы составляли шесть тысяч и больше. Все это налоговым бременем ложилось на пермских людей и становилось причиной оттока населения в «сибирские» и «московские города». Пермский земский судецкий староста Иван Яковлев сын Могильников ${ }^{5}$ и земский человек, чердынец, посадский жилец Михаило Иванов сын Ванков ${ }^{6}$ описали эти проблемы в челобитной на царское имя во второй половине мая 1606 г. ${ }^{7}$ [2, № 54, с. $123-$ 
124; 31, с. 53] . В челобитной также обозначены существовавшие на тот момент ямы и расстояние между ними: от Кайгородка до Верхотурья (500 верст), от Перми до Ужги (405 верст), от Перми до Вятки (500 верст), летом от Перми до Казани водным путем (1000 верст), от Перми до Соли Вычегодской $(1000 \text { верст })^{8}$ [2, № 54, с. 123-124].

Решение проблемы земские выборные люди видели в том, чтобы на Сибирской дороге (на реке Кырье) и в Перми Великой (в Соли Камской и Кайгородке) устроить ямы [2, № 54, с. 123-124], то есть речь шла о трех пунктах, лежавших на пути пересечения дорог между Ужгой и Верхотурьем, между Казанью и Чердынью. Два пункта из них (Соль Камская и река Кырья) приходились на построенную девятью годами ранее дорогу, известную в историографии как Бабиновская дорога (от Соли Камской до Верхотурья). Финансовое обеспечение строительства ямов земские люди предлагали устроить с помощью сошной подати из Перми, Вятки и Каргополя или денежных доходов только из Перми [2, № 54, с. 123-124].

Эта челобитная стала тем самым инициативным документом, на который отреагировали в Москве, и 11 июля 1606 г. от имени царя В.И. Шуйского в Новгородском четвертном приказе дьяки Григорий Елизаров и Нечай Федоров составили указную грамоту в Пермь Великую князю Семену Юрьевичу Вяземскому и подьячему Ивану Федорову об устройстве в Соли Камской яма. Соль Камская географически располагалась между Кайгородком и рекой Кырью, и, вероятно, было рационально начать с организации именно этого яма. Указано было собрать 70 человек охотников с двух земель - из Перми (24 человека) и Вятки (46 человек). Брать следовало только по желанию («охочих» людей) и людей с достатком («прожиточных»). А если не будет хватать желающих, то брать «по сошному розводу», то есть в качестве распределения тягла. Ямщикам было указано держать по 2 лошади, а на лошадей и на дворовое строение следовало собрать средства в Перми и в Вятке «по уговору». Также с этих земель ежегодно предписывалось собирать ямщикам прогонные деньги, а князю С.Ю. Вяземскому велено было выяснить у пермичей, можно ли дополнительно обеспечить ямщиков пашнями и сенными покосами. Данную указную грамоту в Пермь Великую привез 8 сентября 1606 г. сам челобитчик, судецкий староста Иван Могильников [2, № 54, с. 124].

Аналогичная грамота о сборе «охотников» для Соликамского яма была отправлена в Вятку подьячему Василию Иванову. Вятская земля имела самостоятельное административное управление. Из грамоты следовало, что ямщиков необходимо отправить в Пермь Великую, переписав поименно, с поручными записями [2, № 54, с. 124; 37].

Указная грамота была исполнена, и 4 января 1607 г. 70 охотников прибыли в Соль Камскую для ямской службы: 24 человека из Перми Великой (из Чердыни, Усолья и Кайгородка), 46 человек из Вятки. Вятчанам в Вятке дали «подмогу» 1057 рублей (по23 рубля человеку на год) ${ }^{9}[37$, л. 1]. Как отписал пермский приказный человек князь С.Ю. Вяземский, всем охотникам место под дворы дали, «дворы велели ставить и ямскую гоньбу гоняти». Именную роспись ямщиков, поручные записи по ним и книгу земельных дач С.Ю. Вяземский отправил в Москву с пермским подьячим Иваном Федоровым, приложив к своей отписке [29]. Эти именные росписи и книги не сохранились, но, вероятно, речь идет об отправке С.Ю. Вяземским именных росписей и поручных записей только на пермских ямских охотников: ближе к весне 1607 г. С.Ю. Вяземский сообщил в очередной отписке, что ранее высылал поручные записи по 23 пермским ямщикам, а теперь досылает по 24-му [23]. К тому же, когда возникла необходимость розыска сбежавших вятских ямщиков, С.Ю. Вяземский писал, что поручных записей на них у него нет, разыскивать беглецов на территории Вятской земли следует вятскому князю Михаилу Ухтомскому и возвращать их назад на ямскую службу в Пермскую землю $[17 ; 18]$.

В то же время «ямские» и «строельные» книги содержали записи о выдаче мест под дворы как пермским, так и вятским ямщикам (информация пересказывается в царской указной грамоте от 13 сентября 1607 г.): «под дворы и на огороды» дано всего 21 четь в длину, по тридцать сажень в ширину, 15 сажень человеку [38]. 


\section{ИСТОРИЯ СМУТНОГО ВРЕМЕНИ}

С 12 января 1607 г. в Соли Камской стал функционировать ям: ямские охотники начали ямскую гоньбу [26].

Однако уже с середины февраля 1607 г. вятские ямские охотники стали жаловаться вятским земским властям на то, что им в Соли Камской не дают не только пашен, сенных покосов, но и дворов, за все просят денег, они «волочатся меж двор», в то время как у пермичей лишние пашни («за окладами») и «сенные покосы и всякие угодья безоброчные» есть. Приблизительно 20 февраля 1607 г. челобитную об этом царю В.И. Шуйскому написал и отправил вятский земский староста из Хлынова Игнашка Морозов «и во всех вяцкие земли посадцких и волостных людей место» [24; 31, с. 55; 37].

Вероятно зная про недовольство вятчан и предваряя указную грамоту, князь С.Ю. Вяземский примерно в то же время, 22 февраля 1607 г., отправил в Москву отписку с объяснением сложившейся ситуации по земельному вопросу. Расспросив в Соли Камской посадского старосту Ивана Овдокимова, целовальников и посадских людей, князь выяснил, что «порожжих земель» и «безоброчных сенных покосов», которыми надлежало обеспечить охотников Соликамского яма, у них нет. Пашни подошли к посаду, посадские люди владеют ими по крепостям и тягло с них платят. «Порожжие пожни под сенные покосы», включая дальние и болотистые, также все под оброком, собирают с них сено «не в мочливое лето»: в Усольском уезде с одного такого места - 1000 копен («полторы» зачеркнуто), в Чердынском (за старостой Иваном Овдокимовым) - 250 копен («семьсот» зачеркнуто), он платит оброк 2 рубля с чети в год [29].

Дьяки Новгородской чети 25 марта 1607 г. снова настоятельно велели выделить вятским ямским охотникам землю под дворы, сенные покосы и пашни [37]. Князь С.Ю. Вяземский в очередной раз подтвердил, что место под дворы у Соли Камской вятским ямским охотникам выделено, но дворы им должны были ставить «всею вятскою землею... мирскими деньгами». По этому поводу в Москву С.Ю. Вяземский отправил с челобитьем вятского охотника Мартынка Федорова сына Пантелеева, а в Вятку к князю Михаилу Ухтомскому и подьячему Василию Иванову ямского охот- ника Семейку Коткова. Но вопрос на тот момент решен не был [22].

Однако спустя два месяца после начала функционирования Соликамского яма проблем перевозок на Сибирской дороге только прибавилось. В марте 1607 г. от имени усольских ямщиков староста Трофим Ондреев жаловался в челобитной царю о следующем:

1. Воеводы, дети боярские, стрельцы и казаки по пути в Сибирь сильно перегружают подводы: в Соли Камской покупают много мяса, сукно, масло, сало, холсты, кладут «вьючные клади» на подводы и сами на них садятся. В итоге от такой тяжести подводы до Верхотурья не доходят.

2. Стрельцы и казаки отбирают у них подводы насильно сверх того, что указано в подорожных грамотах, «правят на них денег и кормов и насильство всякое чинят».

3. Подводы усольцев насильно используют в Сибирских городах для погони за сбежавшими людьми и за это не платят, что приводит ямщиков к убытку [2, № 71, с. 162-163]. Проводников подвод берут в качестве «бережатых» [26].

Такая же челобитная была подана на имя пермского главы администрации князя С.Ю. Вяземского, после чего князь сам ездил в Соль Камскую разбираться с этим вопросом в начале апреля 1607 г. [20]. Его приезд был как нельзя кстати, поскольку совпал по времени с перегоном большого государева груза.

Ориентировочно в феврале 1607 г. [31, c. 60] из Москвы и Вологды на Верхотурье по царскому указу были отправлены «церковное строенье», образа, книги, колокола для церквей, «судовые запасы», «железо и уклад» для изготовления крестьянам сельскохозяйственных орудий - сошников, кос, серпов и топоров. В составе груза были также денежная казна, сукно, вино церковное, бумага писчая, канаты, паруса, якоря [1, № 42, с. 110; 26]. $\mathrm{B}$ сопровождении детей боярских Матвея Есипова, Семена Бурцева и казачьего атамана Тугарина Федорова 10 апреля 1607 г. груз прибыл в Соль Камскую [17; 26].

Однако большую часть груза довести до Верхотурья не удалось. Как писали в Москву верхотурские воеводы Степан Годунов и Алексей Загрязский со слов сопровождавших груз служилых людей Матвея Есипова и Се- 
мена Бурцева, в середине апреля 1607 г. пришлось все выгрузить в Перми Великой у Соли Камской: «ямщики устроены на яму ново, и они разбежались», «везти не на чем, подвод не дали», «усольцы с земли лошадей не дали» [1, № 81, с. $110 ; 31$, с. 60].

С.Ю. Вяземский, приехав в Соль Камскую, увидел следующую картину: с М. Есиповым и С. Бурцевым одновременно в Соль Камскую прибыли служилые люди: литва, казаки, стрельцы, надеясь проехать по последнему зимнему пути «в роскалье» [26]. И всего нужно было снарядить около 300 подвод [17]. А когда дети боярские и служилые люди стали править подводы, «кормы и посулы великие», вятские ямские охотники сбежали к Вятке. Правежи продолжились на пермичах (усольцах и кайгородцах) - на посадских людях и волостных крестьянах, о чем пермские земские старосты и целовальники писали к царю в челобитных. Князь С.Ю. Вяземский велел сыскать беглых вятских ямских охотников по лесам и деревням, чтобы с ними, а также с пермскими ямщиками отправить государеву казну на Верхотурье. Некоторых белых вятских ямщиков сыскал, а за тех, которых найти не удалось, он заставил поручиться находившихся там вятских торговых людей [26].

Князь С.Ю. Вяземский также написал в Вятку к князю Михаилу Ухтомскому и подьячему Василию Иванову отписку с просьбой найти сбежавших вятских ямщиков по поручным записям и вернуть на ям в Соль Камскую для отправки государева груза в Сибирь. Сам он, как пермский приказный человек, не имел права это делать на Вятской земле, и поручных записей у него не было [17]. Эта отписка сохранилась, в ней перечислено пятеро сбежавших ямщиков и указаны их имена: слобожанин Ерманко Шиврин, Офонька Косарев из Шестакова города, Конашка Петров сын и Ивашко Северухин хлыновцы, Конашка Иванов сын Сысоев из Котелнича [15].

Таким образом, со слов С.Ю. Вяземского, в Соли Камской оставались только 24 пермских ямщика, которые продолжали отпускать сибирские подводы. Треть подвод после начала половодья с Верхотурья не вернулась - «завесновали», как «завесновала» в Соли Камской и большая часть государева груза. С.Ю. Вяземским было принято реше- ние оставить основную часть неотправленного груза в Соли Камской до наступления нового зимнего пути $[17 ; 26]$. С учетом того что по установленным нормам перевозок в летний период вес вьюков был сильно ограничен по сравнению с зимним, это было вынужденное решение.

В то же время в центральной части государства разворачивались активные военные действия. В мае 1607 г. от имени царя было велено подождать с выделением дворов вятским ящикам в связи с возможным призывом некоторых из них на ратную службу в Москву - ямщикам было указано жить в тех же дворах, где они жили к тому моменту. Было также велено усольцам посадским людям беречь ямщиков «от насильства» дворян, детей боярских, казаков, стрельцов, чтобы убытка не было: чтобы «кормов и лишних подвод, кроме подорожных, не имали», платили прогонные в случае привлечения к погоне за беглыми сибирскими колодниками, соблюдали порядок весовых ограничений провоза грузов. Предписывалось зимние клади класть на подводу по 15 пудов, летние вьюки - по 4 пуда при условии, что люди на вьюки сверху садиться не будут. А если кто хочет поехать на подводе, то чтобы брал с собой только еду в дорогу «да по епанче ${ }^{10} »^{11}$. А если кто чью подводу «уморит» и она «от насильства падет», то писать в Москву, и в приказе на виновного будет наложена повинность на возмещение ущерба [3, № 71, с. 162-163].

Таким образом, к июню 1607 г. на выделенных местах дворы начали ставить только пермские ямщики [24], но к июлю и пермские ямщики, глядя на вятских, переставали это делать [18]. 10 июля 1607 г. С.Ю. Вяземский заключил, что если не будет помощи от вятских людей «добрых» в сибирских отпусках «с деньгами» и «для счету в подводах», если их не остановить «от воровства, от бражничества, и от зерни, и от блядни», то «яму вперед не устояти» [26].

Тем временем из Москвы поступали все более гневные указные грамоты. 23 июня 1607 г. было велено из оставленного в Соли Камской раскованного железа сделать косы, серпы, топоры и сошники, заплатив за работу кузнецам, и вместе со всем оставшимся грузом срочно отправить на Верхотурье. Велено было тотчас 


\section{ИСТОРИЯ СМУТНОГО ВРЕМЕНИ}

разыскать беглых ямщиков по поручным записям, организовать ям и смотреть за ними. «А не учнешь вперед... о нашем деле радеть, а которое дело твоей глупостию и оплошкою замотчается, и тебе за то от нас быти в великой опале», - написано в грамоте, полученной в Перми 31 июля 1607 г. [1, № 81, с. 111]. В ответной отписке в августе С.Ю. Вяземский снова повторил уже сообщаемую ранее информацию, что поручных записей на вятских ямщиков у него нет, М. Ухтомский беглых вятских ямщиков в Соль Камскую не присылает [18].

Пока в Пермь шла предыдущая грамота, в Москве 23 июля 1607 г. уже составили новую с еще большим негодованием и возмущением по поводу творимого С.Ю. Вяземским «произвола». В ней есть отсылка к новой челобитной с Вятки - хлыновского земского старосты Игнашки Морозова, где приводится взгляд с другой стороны, почему вятские ямские охотники разбежались:

1. Вятских охотников бьют и мучают «без вины напрасно» как раз для того, чтобы они разбежались, а гоньбу гоняли бы не ямщики, а по-прежнему, посадские люди и волостные крестьяне. А пермичи намеревались, со слов старосты, брать с Вятки только прогонные деньги, «приклепывая прогонов, и корыстоваться теми деньгами самим».

2. Весной 1607 г. часть вятских охотников поехали по последнему зимнему пути на Верхотурье с государевой казной, якорями и парусами, а назад вернуться не успели - «завесновали» на Верхотурье. Другие были отпущены к Москве и в Вятку погостить. И все они были записаны в беглые, а правил С.Ю. Вяземский за них на вятчанах - торговых людях, которые были в то время в Соли Камской, чтобы отправить подводы и гребцов, и это принесло им значительный убыток.

3. Послал С.Ю. Вяземский с деньгами литвина на Верхотурье купить жернов, а деньги утонули. Так те деньги было велено «доправить» снова на вятских торговых людях «насильством».

4. Вятским ямским охотникам дворы, пашни и сенные покосы, «безоброчные» и «безденежные», так даны и не были, а прожить без них было невозможно. А когда вятчане послали челобитную об этом в Москву, то посыльщика убили и изувечили [2, № 78, с. 171].
Все происходившее возмущало дьяков в Новгородской чети, которые писали С.Ю. Вяземскому: «...велено тебе у Соли Камской ям строити, а не розогнати». Указано ему также было «не дуровать, ямщиков без вины напрасно не бить, не разгонять, дать места под дворы, пашни и сенные покосы безволокитно». В дополнение в Пермь был направлен из Москвы подьячий Леонтий Софонов для совместного с князем С.Ю. Вяземским решения всех вопросов и судебных дел над посадскими людьми и волостными крестьянами. «А если впредь поступят жалобы от вятчан, писали князю С.Ю. Вяземскому дьяки Новгородской чети, - то те их убытки... доправити на тебе вдвое, без суда... и быть в великой опале» [2, № 78, с. 170-172].

В свое оправдание на эти обвинения князь С.Ю. Вяземский писал в сентябрьской отписке следующее:

1. Когда приехал в Соль Камскую, то земские и ямские старосты рассказали о «воровстве» охотников, о том, что они «живут на корчме, пьют, и бражничают, и зернью играют, и $з$ блядми воруют». За это князь велел их бить батогами.

2. По челобитной вятских же ямщиков Ермолки с товарищами вятские торговые люди Трофимко Погудин с товарищами были поручиками у беглых вятских ямщиков, и «сибирские отпуски отпускали не правежом, а хто по ком порука».

3. Литвина с деньгами жернов купить князь не посылал. Это был литвин из Тобольска Трофим, который ехал из Москвы с государевыми деньгами (5 руб. 20 алтын), предназначенными для покупки жерновов, и с колодниками. Вятский ямщик Первушка вез его от Соли Камской до Верхотурья и потопил сани и сумку с деньгами. Литвин бил челом на ямщика, прошел суд, на котором ямщик был объявлен виновным и был обязан возместить деньги литвину.

4. Под дворы места были выделены, взяли их у посадских людей, а о том, чьи земли и сенные покосы вокруг посада Соли Камской и что безоброчных нет, было сообщено в отписке в Москву еще весной, после чего никакие конкретные указания из Москвы не поступали [21].

После Ильина дня, 20 июля 1607 г., пошли сильные дожди, и все мосты через реки 
и речки по Сибирской дороге от Соли Камской до Верхотурья смыло. И если ранее их мостили посадские люди чердынцы, усольцы и кайгородцы «всею пермскою землею», то теперь они эту работу делать отказались, сославшись на то, что ямщики «теми дорогами гоняют, они де и мосты мостят». По этому поводу князь С.Ю. Вяземский 18 августа 1607 г. спрашивал государя о том, кому он велит мосты мостить, чтобы обеспечить путь «государевой казны» из Сибири [28].

Ответ был подготовлен только 18 октября 1607 г., указная грамота доставлена в Пермь 5 января 1608 года. В ней было предписано «мосты мостить посадским и волостным людям по-прежнему... ....А ямщики нигде мостов не мостят» [2, № 80, с. 172].

Часть задержавшейся в Соли Камской «государевой казны» князю С.Ю. Вяземскому удалось отправить на Верхотурье с вятским и пермским ямщиками Званкой Северухиным и Сонкой Обросимовым с товарищами 20 августа 1607 года. Были отправлены «кубанные и бевченые веревки» 389 сажен, 946 аршин холста на паруса. Церковные строения, образа и колокола, судовые большие канаты ямщики не повезли. Раскованное железо князь С.Ю. Вяземский раздал ковать в сохи, топоры, косы, серпы по царскому указу в Соли Камской [27 ${ }^{12}$ ].

4 сентября 1607 г. в Соли Камской была проведена поименная перепись ямщиков, у которых были лошади $\left[16^{13}\right.$, л. 4, 3], 5 сентября - у которых не было лошадей [16, л. 2]. Проводил ее лично князь С.Ю. Вяземский в Соли Камской, из чего заключил, что у пермских ямщиков было по 2 мерина на человека, у вятских - лошадей мало, а у некоторых совсем не было: ямщики их или перепродали, или лошади попадали $[16$, л. 1,5$]$. Перепись от 4 сентября полная, она содержит имена всех сорока вятских ямщиков с указанием, у кого сколько лошадей было или не было. Перепись от 5 сентября содержит только 6 имен тех ямщиков, у кого лошадей не было, при этом информация не совсем полная, дублируется со списком от 4 сентября. Эти росписи 9 ноября 1607 г. вместе со своей отпиской князь С.Ю. Вяземский отправил в Москву в Новгородскую четь.
Таким образом, в общей сложности удается восстановить имена 48 вятских ямщиков. 40 человек известно по списку от 4 сентября 1607 г., остальные 8, включая старосту, дополнены по отпискам князя С.Ю. Вяземского ${ }^{14}$.

Итак, в начале сентября 1607 г. в Соликамском яме было 39 вятских ямщиков (изсорока один сбежал). Список показывает, что из ранее сбежавших на Вятку пятерых ямщиков, о которых князь С.Ю. Вяземский писал М. Ухтомскому, вернулись 4 человека, причем два из них были десятские: Ермак Шиврин (десятский), Офонька Косарев (десятский), Конашка Петров, Ивашко Северухин ${ }^{15}$. Имени беглого ямщика Конашки Иванова сына Сысоева в сентябрьских списках нет. Таким образом, видим, что почти все вятские ямщики, сбежавшие в апреле - мае 1607 г., к осени были возвращены (напомним, что в январе 1607 г. было прислано 46 человек).

Проблема была в другом: не хватало лошадей. На 39 человек насчитывалось 50 лошадей, то есть норма в 2 лошади на человека не соблюдалась. Причем у некоторых ямщиков лошадей не было совсем. Новых лошадей они не купили, как говорили сами, потому что нанялись у посадских людей и волостных крестьян быть на ямской службе до Филиппова заговенья и как срок придет, «хотят с яму збежати к Вятке». Князь С.Ю. Вяземский писал, что как только они сбегут, ям будет пуст и «пермским... ямщиком одним твоих государевых отпусков не угоняти (данная фраза была зачеркнута. - H. P.)» $[16$, л. 1,5$]$.

9 октября 1607 г. князь С.Ю. Вяземский сообщил, что сбежали вятские ямские охотники Хлынова города Трофимка Андреев сын Погудин и Слободского города Гришка Яковлев сын Черезов, и у него поручных записей на них нет, поэтому искать их он не может [27]. Примерно в то же время сбежали вятские ямщики Слободского города Костя Орефин, брат Гришки Черезова Филка Черезов, Афонька Косарев (десятский), Михалко Суровцов, Илейка Макаров, «и остальные хотят с яму разбежаться» [19].

Только осенью, 13 сентября 1607 г., в Новгородской чети дьяками Григорием Елизаровым и Андреем Ивановым была подготовлена царская указная грамота с разъяснениями, каким образом нужно обеспечить ямщиков пашнями и 
сенными покосами в условиях отсутствия свободных безоброчных земельных ресурсов. Эту грамоту получили в Перми 19 ноября 1607 г. ([38]; публ.: [31, № 22, с. 204-209]). Однако дворы вятские ямщики ставить отказались, как отказались брать землю под пашню и сенные покосы, ожидая срока окончания своей службы [25 16].

По «противным записям» вятчанам предписано было стоять на Соликамском яме «до Филипповы заго[вей]ны на 116-м году», то есть до 14 ноября 1607 г., а пермским ямщикам - «до Крещения Христова 116 года», то есть до 6 января 1608 г., но до этих сроков они стоять не собирались [18].

В отписке князя С.Ю. Вяземского от 25 декабря 1607 г. сообщалось, что 23 декабря 1607 г. сбежали вятские охотники Хлынова города староста Тимошка Константинов с братом, взяли ямские книги и с подорожных списки, а с ними почти все последние вятские ямщики (перечислены 24 человека, что отражено в таблице), то есть вятские ямщики пробыли на яме даже дольше отведенного им срока, вместе с пермскими, почти до Рождества [25].

28 декабря 1607 г. на Вятке воевода князь М.Ф. Ухтомский и подьячий Василий Иванов получили грамоту царя В.И. Шуйского с указанием отозвать из Соли Камской вятских ямских охотников, три указные царские грамоты были отправлены в Пермь князю С.Ю. Вяземскому также 28 декабря 1607 г. [2, № 82, с. 176; 13]. Дошли эти грамоты 5 января 1608 г., о чем С.Ю. Вяземский отписал на Вятку князю М.Ф. Ухтомскому и подьячему В. Иванову [14]. По этим грамотам велено было отпустить вятских охотников и впредь не приглашать для ямской службы, а заниматься ямской гоньбой «пермичам по-прежнему». Ямские книги и с подорожных списки князь С.Ю. Вяземский указал прислать к нему в Чердынь, а если не отдадут, то прислать вятского ямского старосту с книгами [30]. Последнее распоряжение не совсем понятно, так как князь С.Ю. Вяземский еще 25 декабря знал, что староста с книгами уехал в Вятку.

Результаты. Итак, на территории Перми Великой, в Соли Камской, расположенной на Сибирской дороге, с целью решения проблем грузоперевозок в 1607 г. была предпринятая попытка создания нового яма. Сам ям был организован в соответствии с уже суще- ствовавшей практикой ямской службы: ямщики были разбиты на десятки во главе с десятскими, из ямской среды происходил и ямской староста, который занимался непосредственным управлением и ведением документации в яме. О наличии ямского приказчика, как часто бывало в других ямах, в соликамских документах не упоминается. Руководил всем процессом в регионе пермский приказный человек, чья изба находилась в Чердыни. Он выполнял прямые распоряжения ведомства центрального аппарата управления - Новгородского четвертного приказа.

Ям функционировал один год, но закончилось все полным провалом. Сохранившийся комплекс документов демонстрирует нам двойственность ситуации. С одной стороны, мы видим функционирование строго централизованной системы управления, с другой стороны, наблюдаем проявления сильной земской власти на местах.

Пермский приказный человек князь С.Ю. Вяземский был поставлен в жесткие рамки: он должен был четко исполнять распоряжения Москвы и был лишен возможности принимать собственные решения. Осложнялась ситуация долгой дорогой: из Перми до Москвы почтовая корреспонденция шла от месяца до двух с половиной в одну сторону. К тому же в ответной грамоте из приказа не всегда содержалось ожидаемое решение, как с местами под пашню и сенными покосами для ямских охотников.

С.Ю. Вяземского нельзя назвать плохим управленцем: вопрос с выделением земли под пашни и сенные покосы ямщикам единолично он решить не мог, но большую часть сбежавших ямских охотников ему вернуть удалось. По сложившейся практике земские старосты писали челобитные напрямую в Москву, служилые люди, ответственные за выполнение царских указов, докладывали о состоянии дел в своих отписках. Отпискам С.Ю. Вяземского в Москву с разъяснением ситуации нельзя не верить: несмотря на отдаленное расположение приуральского региона, истинное положение вещей все равно бы вскрылось. Сохранившийся актовый материал показывает, с какой щепетильностью и в Москве, и на местах относились к формуляру документов: предшествующий документ цитировался в ответном с особой тщательностью. 


\section{Вятские ямские охотники в 1607 г. в Соли Камской}

\begin{tabular}{|c|c|c|c|}
\hline $\begin{array}{c}\text { № } \\
\Pi / \Pi\end{array}$ & Фамилия (отчество), имя & Кол-во лошадей & Примечание \\
\hline \multicolumn{4}{|c|}{ По переписям 4 и 5 сентября 1607 г. } \\
\hline \multicolumn{4}{|c|}{ Из десятка Семейки Коткова: } \\
\hline 1 & Копытов Иванко & 1 & - \\
\hline 2 & $\begin{array}{l}\text { Котков Гаврилка } \\
\text { (сын Семейки Коткова) } \\
\end{array}$ & \multirow{2}{*}{3 на двоих с сыном } & - \\
\hline 3 & $\begin{array}{l}\text { Котков Семейка } \\
\text { (десятский; отец Гаврилки Коткова) }\end{array}$ & & - \\
\hline 4 & Макаров Илейка & $\begin{array}{l}\text { 1; } 1 \text { лошадь пала под казаком } \\
\text { Тюменского города Григорием } \\
\text { Гавриловым }\end{array}$ & Сбежал осенью 1607 г. \\
\hline 5 & Погудин Афонька & $\begin{array}{l}\text { Нет; 1-я лошадь пала под Матфе- } \\
\text { ем Есиповым, 2-я - под паном цы- } \\
\text { ганом Тюменского города }\end{array}$ & Сбежал 23 декабря 1607 г. \\
\hline 6 & Погудин Трошка Андреев сын & Нет & $\begin{array}{l}\text { Сбежал в сентябре } 1607 \text { г. в } \\
\text { момент составления переписи }\end{array}$ \\
\hline 7 & Северухин Иван & \multirow{2}{*}{ 3, с братом на 2 пая } & \multirow[t]{2}{*}{ Сбежали 23 декабря 1607 г. } \\
\hline 8 & Северухин Федоско & & \\
\hline 9 & Суровцов Мишка (Михалко) & 1 & Сбежал осенью 1607 г. \\
\hline 10 & Шишкин Тимошка & $\begin{array}{l}\text { 1; } 1 \text { лошадь пала под Семеном } \\
\text { Бурцевым }\end{array}$ & Сбежал 23 декабря 1607 г. \\
\hline \multicolumn{4}{|c|}{ Из десятка Тимочки Арефина: } \\
\hline 11 & Арефин Тимоша (десятский) & 1 с 2 паев & - \\
\hline 12 & Макин Гришка & 1 & Сбежал 23 декабря 1607 г. \\
\hline 13 & Остафьев Игнашка & Нет & Сбежал 23 декабря 1607 г. \\
\hline 14 & Пантелеев Мартынко & 2 & $\begin{array}{l}\text { Сбежал } 23 \text { декабря } 1607 \text { г. с } \\
\text { двумя братьями }\end{array}$ \\
\hline 15 & Пенкин Фетка & 3 с 2 паев & - \\
\hline 16 & Петров Конашка & 2 & - \\
\hline 17 & Присыпкин Юрка & 1 & Сбежал 23 декабря 1607 г. \\
\hline 18 & Титов Семейка & 1 & - \\
\hline \multicolumn{4}{|c|}{ Из десятка Козьмы Батуева: } \\
\hline 19 & Батуев Козма (десятский) & 1 & - \\
\hline 20 & Горбунов Иванка & 1 & Сбежал 23 декабря 1607 г. \\
\hline 21 & Исаев Конашка & 1 & Сбежал 23 декабря 1607 г. \\
\hline 22 & Мычелка Васька & 2 & - \\
\hline 23 & Сагадаков Иванко & Нет & - \\
\hline 24 & Юркин Бажен & Нет & - \\
\hline \multicolumn{4}{|c|}{ Из десятка Афони Косарева: } \\
\hline 25 & Косарев Афоня (десятский) & 3 с 2 паев на двоих & $\begin{array}{l}\text { В более ранней отписке указа- } \\
\text { но, что сбежал осенью [19], } \\
\text { позже - что } 23 \text { декабря } 1607 \text { г. } \\
\text { [25]. Верно второе }\end{array}$ \\
\hline 26 & Перминов Меньшик & & Сбежал 23 декабря 1607 г. \\
\hline 27 & Пестов Афоня & 3 с 3 паев & - \\
\hline 28 & Желункин Левка & 1 & - \\
\hline 29 & Пестов Рычко & 1 & - \\
\hline 30 & Скоморохов Иванко & 1 & Сбежал 23 декабря 1607 г. \\
\hline 31 & Шабалин Олеша & 1 & - \\
\hline 32 & Шестаковец Первуша & 2 & - \\
\hline \multicolumn{4}{|c|}{ Из десятка Ермака Шиврина: } \\
\hline 33 & Воронин Алеша & 2 & Сбежал 23 декабря 1607 г. \\
\hline 34 & Головизнин Первушка & 1 & Сбежал 23 декабря 1607 г. \\
\hline 35 & Дулов Семейка (Сенька) & 1 & Сбежал 23 декабря 1607 г. \\
\hline 36 & Морозов Филка & 2 & Сбежал 23 декабря 1607 г. \\
\hline 37 & Саврасов Молчанко & 2 & - \\
\hline 38 & Симахин Данилко & 1 & Сбежал 23 декабря 1607 г. \\
\hline 39 & Черезов Филька & Нет & $\begin{array}{l}\text { В более ранней отписке указа- } \\
\text { но, что сбежал осенью [19], } \\
\text { позже - что } 23 \text { декабря } 1607 \text { г. } \\
\text { [25]. Верно второе }\end{array}$ \\
\hline 40 & Шиврин Ермак (десятский) & $\begin{array}{l}3 \text {, в переписи от } 05.09 .1607- \\
2 \text { с } 3 \text { паев }\end{array}$ & - \\
\hline 41 & $\begin{array}{l}\text { Ямской староста: } \\
\text { Константинов Тимофей }\end{array}$ & Нет свед. & Сбежал 23 декабря с братом \\
\hline
\end{tabular}


Окончание таблицьь

\begin{tabular}{|c|c|c|c|}
\hline $\begin{array}{l}\text { № } \\
\Pi / \Pi\end{array}$ & Фамилия (отчество), имя & Кол-во лошадей & Примечание \\
\hline \multicolumn{4}{|c|}{ На 4-5 сентября уже не было, но упоминаются в документах ранее } \\
\hline 42 & Северухин Званка & Нет свед. & - \\
\hline 43 & Сысоев Конашка Иванов сын & Нет свед. & $\begin{array}{l}\text { Сбежал в мае } 1607 \text { г в Вятку, не } \\
\text { вернулся }\end{array}$ \\
\hline \multicolumn{4}{|c|}{ На 4-5 сентября не упоминаются, но значатся как сбежавшие позже } \\
\hline 44 & Черезов Гришка Яковлев сын & Нет свед. & Сбежал в октябре 1607 г. \\
\hline 45 & Орефин Костя & Нет свед. & Сбежал осенью 1607 г. \\
\hline 46 & Рычков Сенька & Нет свед. & Сбежал 23 декабря 1607 г. \\
\hline 47 & Ондреев Кондратий & Нет свед. & Сбежал 23 декабря 1607 г. \\
\hline 48 & Павлов Илейка & Нет свед. & Сбежал 23 декабря 1607 г. \\
\hline
\end{tabular}

В то же время нельзя не верить челобитным земского вятского старосты, в которых конфликтные ситуации представлены порой с прямо противоположной стороны. Однако следует отделять факты от домыслов. Так, вызывает сомнение высказанное в отношении князя С.Ю. Вяземского обвинение о якобы существовавшем его сговоре с соликамскими земскими старостами с целью выдворения вятчан с ямской службы. Здесь неясна мотивация князя, отправленного на приказную службу в Пермь Великую на 2 года, саботировать ответственное государственное дело по организации нового яма и переправке государевого груза в Сибирь, тем более что в его собственных отписках встречаются неоднократные восклицания о том, что без участия вятских ямщиков ям поддерживать не удастся.

Становится очевидным, что самой заинтересованной стороной в том, чтобы не допустить оседания в Пермской земле вятских ямщиков, являлись именно посадские люди и крестьяне Соли Камской во главе со старостой. Староста составил земельное описание для князя С.Ю. Вяземского с утверждением, что безоброчных земель нет, хотя именно ему принадлежала часть болотистой территории, о которой он сам указал особо. Не совсем понятно, правда, основание для занижения сумм оброка, которые мы видим в сохранившемся черновике отписки князя С.Ю. Вяземского.

Таким образом, данная история демонстрирует сильную земскую выборную власть на местах, со скрытыми намерениями которой не смогли справиться ни дьяки Новгородского приказа, ни представитель приказного управления князь С.Ю. Вяземский непосредственно в Перми Великой.
В то же время ключевые финансовые вопросы, которые обеспечивали бы яму стабильную бесперебойную работу, в Новгородской четверти изначально продуманы не были. Было неясно, какими именно землями наделить ямщиков, на чьи средства ямщики должны были поставить свои дома, кто должен был им покупать лошадей в сложных условиях грузовых перевозок по Сибирской дороге, восполняя потери при их падении, кто должен был осуществлять сезонный ремонт дорог и мостов и за чей счет.

Распоряжение из Москвы по земельному вопросу поступило с опозданием в год, а в условиях разгоравшейся в центре страны гражданской войны необходимость сбора средств с отдаленного стабильного региона была все ощутимее. Центральную власть заботила своевременная отправка налоговых сборов в Москву, о чем неоднократно поступали указные грамоты в Пермь Великую на протяжении всего 1607 года. О выделении дополнительных средств на обустройство и поддержание функционирования яма речи не было.

После роспуска ямщиков Соликамского яма проблема перевозок на Сибирской дороге опять себя проявила: весной 1608 г., аналогично весне 1607 г., новый государев груз из Москвы на Верхотурье застрял в Соли Камской. Решением вопроса занимался уже приказный человек Ф.П. Акинфов, сменивший князя С.Ю. Вяземского.

\section{ПРИМЕЧАНИЯ}

${ }^{1}$ Исследование осуществлено при поддержке РФФИ, грант № 15-31-01202(а2) «Институты го- 
сударственного управления в России в Смутное время начала XVII века».

${ }^{2}$ В документах начала XVII в. ее называют Сибирской дорогой.

3 О датах начала строительства дороги в историографии единого мнения нет.

${ }^{4}$ И.Я. Гурлянд описал этот сюжет весьма кратко, основываясь на четырех опубликованных документах, что, конечно, не дало возможности глубоко изучить произошедшие события.

5 По отписи от 21 февраля 1606 г. [31, с. 184].

${ }^{6}$ Михаило Иванов сын Ванков в 1605 и 1606 гг. значится в перечне земских людей чердынцев, посадских жильцов [31, с. 170, 193].

7 Текст челобитной до наших дней не сохранился, реконструируется на основе упоминания в указной грамоте, однако ввиду того что она была составлена в середине мая, а информация о воцарении В.И. Шуйского дошла до Перми Великой только в середине июня, можно предположить, что она была составлена на имя «царя Дмитрия Ивановича».

8 Пермью называли главный город Перми Великой Чердынь в документах, адресованных из Москвы всей Пермской земле.

9 Годовое жалованье в 23 рубля оценивается исследователями как большое [7, с. 203], оно сопоставимо с денежным жалованьем ямских охотников Новгородского яма Псковской дороги, организованного в 1586-1587 гг., - по 20 рублей (первоначально планировалось по 25 рублей) [5, с. 98-100], а также Верхотурского яма в момент его устройства в 1600 г. - по 20 рублей на пай [7, с. 203].

10 Древнерус.: «безрукавный плащ».

11 И.Я. Гурлянд, цитируя документ в части размеров ограничения веса, допустил ошибку, указав 1609 г. вместо 1607 г. [5, с. 203].

12 Идентификация составных частей одного документа проведена по почерку и смыслу.

${ }^{13}$ В архивном документе листы перепутаны. Отписка князя С.Ю. Вяземского находится на л. 1, 5, перепись ямщиков от 4 сентября - на л. 4 (начало) и 3 (окончание), перепись ямщиков от 5 сентября нал. 2.

14 Можно предположить, что из указанных 7 кто-то упомянут в таблице дважды (к примеру, в одном документе он мог быть назван по имени и отчеству, в другом - по имени и фамилии) либо какой-то ямщик был взят на службу в 1607 г. дополнительно на освободившиеся паи.

15 В списке Ивашко Северухин упомянут без имени, как брат Федоски Северухина. Однако в отписке князя В.Ю. Вяземского от 25 декабря он уже назван полным именем и отмечалось, что сбежал 23 декабря.

16 Идентификация составных частей одного документа проведена по почерку и смыслу.

\section{СПИСОК ЛИТЕРАТУРЫ}

1. Акты исторические, собранные и изданные Археографическою комиссиею. В 5 т. Т. 2. (1598-1613 гг.). - СПб. : Тип. Экспедиции заготовления гос. бумаг, 1841. -482 с.

2. Акты, собранные в библиотеках и архивах Российской империи археографическою экспедициею императорской академии наук. В 4 т. Т. 2. - СПб. : Тип. ІІ отд-ния Собств. Е.И.В. Канцелярии, 1836. - 392 с.

3. Бахрушин, С. В. Очерки по истории колонизации Сибири в XVI и XVII вв. / С. В. Бахрушин. М. : М. и С. Сабашниковы, 1927. - 198 с.

4. Государева дорога «Бабиновская». - Электрон. текстовые дан. - Режим доступа: http://www. gosudarevadoroga.ru/ (дата обращения: 01.03.2019). Загл. с экрана.

5. Гурлянд, И. Я. Ямская гоньба в Московском государстве до конца XVII века / И. Я. Гурлянд. - Ярославль : Тип. губерн. правл., 1900. - 345 с.

6. История Урала с древнейших времен до 1861 г. - М. : Наука, 1989. - 608 с.

7. Катионов, О. Н. Московско-Сибирский тракт и его жители в XVII-XIX вв. / О. Н. Катионов. 2-е изд. - Новосибирск : Изд-во НГПУ, 2014. - 576 с.

8. Космовская, А. А. Воеводское управление в Пермском Прикамье в конце XVI - XVII вв. : дис. ... канд. ист. наук / Космовская Анна Алексеевна. Пермь, 2015. - 254 с.

9. Лаппо-Данилевский, А. С. Организация прямого обложения в Московском государстве со времен Смуты до эпохи преобразований / А. С. Лаппо-Данилевский. - СПб. : Тип. И.Н. Скороходова, 1890. $-579 \mathrm{c}$.

10. Миллер, Г. Ф. История Сибири. В 3 т. Т. 1 / Г. Ф. Миллер. - М. ; Л. : Изд-во АН СССР, 1937. $607 \mathrm{c}$.

11. Николаев, Ю. К. Большая «государева дорога» в Сибирь на участке от Кай-городка до Соликамска через села Юксеево и Коса / Ю. К. Николаев // География и туризм : сб. науч. тр. - Пермь : Издво ПГУ, 2011. - Вып. 10. - С. 73-88.

12. Оборин, В. А. Заселение и освоение Урала в конце XI - начале XVII веков / В. А. Оборин. Иркутск : Изд-во Иркут. ун-та, 1990. - 168 с.

13. Отписка вятского воеводы кн. М.Ф. Ухтомского и подьячего Василия Ивановича в Пермь кн. С.Ю. Вяземскому об отпуске вятских ямщиков ..., 28 декабря 1607 г. // Архив Санкт-Петербургского института истории Российской академии наук (СПбИИ РАН), - Кол. 122. - Оп. 1. - № 65. - 1 л.

14. Отписка из Перми кн. С.Ю. Вяземского в Вятку воеводе кн. М.Ф. Ухтомскому и подьячему Василию Иванову ... об отпуске из Соли Камской вятских ямщиков, 5 января 1608 г. // Архив СПбИИ РАН. - Кол. 122. - Оп. 1. - № 68. - 1 л. 
15. Отписка из Перми кн. С.Ю. Вяземского в Вятку воеводе кн. М.Ф. Ухтомскому и подьячему Василию Иванову о розыске вятских ямщиков, бежавших с Соликамского яма, до 1 сентября 1607 г. // Архив СПбИИ РАН. - Кол. 122. -Оп. 2. - № 18. - 1 л.

16. Отписка из Перми кн. С.Ю. Вяземского и переписи вятским ямщикам, которые имели лошадей, 4 и 5 сентября 1607 г. // Архив СПбИИ РАН. Кол. 122. - Оп. 2. - № 14. - 5 л.

17. Отписка из Перми кн. С.Ю. Вяземского о невозможности отпустить из Соли Камской в Сибирь прибывших из Москвы детей боярских М. Есипова и С. Бурцова и казачьего атамана Т. Федорова вследствие побега вятских ямщиков, май 1607 г. // Архив СПбИИ РАН. - Кол. 122. - Оп. 2. - № 4. - 3 л.

18. Отписка из Перми кн. С.Ю. Вяземского о ненахождении в Соли Камской поручных записей по вятским ямским охотникам ..., до 1 сентября 1607 г. // Архив СПбИИ РАН. - Кол. 122. - Оп. 2. № 10. -2 л.

19. Отписка из Перми кн. С.Ю. Вяземского о побеге вятских ямщиков с Соликамского яма, между 5 сентября и 14 ноября 1607 г. // Архив СПбИИ РАН. - Кол. 122. - Оп. 2. - № 15. - 1 л.

20. Отписка из Перми кн. С.Ю. Вяземского о поездке его в Соль Камскую для расследования жалоб ямских охотников на притеснения проезжих служилых людей ..., 6 апреля 1607 г. // Архив СПбИИ РАН. - Кол. 122. - Оп. 2. - № 3. - 2 л.

21. Отписка из Перми кн. С.Ю. Вяземского о получении им царской грамоты с несправедливым будто бы порицанием его за притеснения вятских ямщиков ..., после 4 сентября 1607 г. // Архив СПбИИ РАН. - Кол. 122. - Оп. 2. - № 11. - 6 л.

22. Отписка из Перми кн. С.Ю. Вяземского о посылке в Москву для челобитья ямского охотника, присланного с Вятки, Мартына Федорова, после 22 февраля 1607 г. // Архив СПбИИ РАН. Кол. 122. - Оп. 2. - № 2. -2 л.

23. Отписка из Перми кн. С.Ю. Вяземского о посылке в Москву поручных записей по ямщикам Соликамского яма, после 4 января - февраль 1607 г. // Архив СПбИИ РАН. - Кол. 122. - Оп. 2. № 19. -1 л.

24. Отписка из Перми кн. С.Ю. Вяземского о привезенной к нему из Вятки царской грамоты ..., 14 июня 1607 г. // Архив СПбИИ РАН. - Кол. 122. Оп. 2. - № 5. -2 л.

25. Отписка из Перми кн. С.Ю. Вяземского об отказе вятских ямщиков на Соликамском яме от отведенных им пашен и сенных покосов и побеге их с яма, 25 декабря 1607 г. // Архив СПбИИ РАН. Кол. 122. - Оп. 2. - № 16. - 2 л. (начало) ; № 17. - 1 л. (окончание).

26. Отписка из Перми кн. С.Ю. Вяземского об отпуске из Соли Камской на Верхотурье приехав- ших из Москвы служилых людей ..., 10 июля 1607 г. // Архив СПбИИРАН. - Кол. 122. - Оп. 2. - № 7. -4 л.

27. Отписка из Перми кн. С.Ю. Вяземского об отпуске на Верхотурье оставленных служилыми людьми в Соли Камской судоходных запасов, 9 октября 1607 г. (окончание) // Архив СПбИИ РАН. Кол. 122. - Оп. 2. - № 9. - 1 л. (начало) ; № 13. - 1 л. (окончание).

28. Отписка из Перми кн. С.Ю. Вяземского с просьбою прислать указ о том, кому надлежит чинить мосты на Сибирской дороге, 18 августа 1607 г. // Архив СПбИИРАН. - Кол. 122. - Оп. 2. - № 8. - 1 л.

29. Отписка из Перми кн. С.Ю. Вяземского об устройстве Соликамского яма и наделении землею ямских охотников, 22 февраля 1607 г. // Архив СПбИИ РАН. - Кол. 122. - Оп. 2. - № 1. - 3 л.

30. Память из Перми кн. С.Ю. Вяземского соликамскому старосте Ивану Пядышеву ... об отпуске из Соли Камской вятских ямщиков ..., 5 января 1608 г. // Архив СПбИИ РАН. - Кол. 122. - Оп. 1.№ $67 .-1$ л.

31. Рыбалко, Н. В. Соликамский архив: реконструкция и источниковедческий анализ (16051608 годы) / Н. В. Рыбалко, Е. Г. Дмитриева. - Волгоград : Изд-во ВолГУ, 2017. - 319 с.

32. Савенкова, Н. М. Бабиновская дорога: новый взгляд / Н. М. Савенкова // Соликамский краеведческий музей. - Электрон. текстовые дан. - Режим доступа: http://skm.solkam.ru/o-muzee/\%D0\%B F $\% \mathrm{D} 1 \% 83 \% \mathrm{D} 0 \% \mathrm{~B} 1 \% \mathrm{D} 0 \% \mathrm{BB} \% \mathrm{D} 0 \% \mathrm{~B} 8 \% \mathrm{D} 0 \% \mathrm{BA} \% \mathrm{D} 0 \%$ B0\%D1\%86\%D0\%B8\%D0\%B8/istoriya-solikamska/ babinovskaya-doroga-novyiy-vzglyad/ (дата обращения: 28.02.19). - Загл. с экрана.

33. Семенов, О. В. Восстановление системы регулярного сообщения в Тюменском уезде в конце 20-х гг. XVII в. / О. В. Семенов // Известия Уральского государственного университета. Серия 2, Гуманитарные науки. - 2010. - № 3 (79). C. 63-72.

34. Семенов, О. В. О времени возникновения системы регулярного сообщения в Сибири / О. В. Семенов // Известия Алтайского государственного университета. -2010. - №4-2 (68). -С. 198-200.

35. Семенов, О. В. Становление и эволюция системы местного управления на Урале во второй половине XV - первой половине XVII в. / О. В. Семенов. - Екатеринбург : Банк культ. информ., 2006. $292 \mathrm{c}$.

36. Семенов, О. В. Ямские приказчики в Западной Сибири в XVII в. / О. В. Семенов // Гуманитарные науки в Сибири. - 2011. - № 1. - С. 7-10.

37. Указная грамота царя В.И. Шуйского в Пермь Великую кн. С.Ю. Вяземскому о безденежной даче вятским ямским охотникам ... дворов, пашен и сенных покосов, 25 марта 1607 г. // Архив СПбИИ РАН. - Кол. 122. - Оп. 1. - № 34. - 2 л. 
38. Указная грамота царя В.И. Шуйского в Пермь Великую кн. С.Ю. Вяземскому о разверстке ямской повинности ..., 13 сентября 1607 г. // Архив СПбИИ РАН. - Кол. 122. - Оп. 1. - № 47. - 6 л.

39. Чагин, Г. Н. На древней Пермской земле / Г. Н. Чагин. - М. : Искусство, 1988. - 176 с.

40. Semenov, O. V. Community Organization of Siberian Coachmen in Late XVI - XVII Centuries / O. V. Semenov // Bylye Gody. - 2014. - № 32 (2). P. 233-238. - In Russian.

\section{REFERENCES}

1. Akty istoricheskie, sobrannye i izdannye Arkheograficheskoy komissieyu. V 5 t. T. 2. (15981613 gg.) [Historical Acts Collected and Published by the Archaeographic Commission. In 5 vols. Vol. 2 . (1598-1613)]. Saint Petersburg, Tipografiya Ekspeditsii zagotovleniya gosudarstvennykh bumag, 1841. $482 \mathrm{p}$.

2. Akty, sobrannye v bibliotekakh i arkhivakh Rossiyskoy imperii arkheograficheskoyu ekspeditsieyu imperatorskoy akademii nauk. $V 4 t$. T. 2 [Acts Collected in Libraries and Archives of the Russian Empire by the Archaeographic Expedition of the Imperial Academy of Sciences. In 4 vols. Vol. 2]. Saint Petersburg, Tipografiya II Otdeleniya Sobstvennoy E.I.V. Kantselyarii, 1836. 392 p.

3. Bakhrushin S.V. Ocherki po istorii kolonizatsii Sibiri $v$ XVI $i$ XVII vv. [Essays on the History of Siberia Colonization in the $16^{\text {th }}$ and $17^{\text {th }} \mathrm{c}$.]. Moscow, M. i S. Sabashnikovy, 1927. 198 p.

4. Gosudareva doroga "Babinovskaya» ["Babinovskaya" Government Road]. URL: http:// www.gosudarevadoroga.ru/ (accessed 1 March 2019).

5. Gurlyand I.Ya. Yamskaya gonba v Moskovskom gosudarstve do kontsa XVII veka [Yamskaya Chase in the Moscow State until the Late $17^{\text {th }}$ c.]. Yaroslavl, Tipografiya gubernskogo pravleniya, $1900.345 \mathrm{p}$.

6. Istoriya Urala $s$ drevneyshikh vremen do $1861 \mathrm{~g}$. [History of the Urals from Ancient Times to 1861]. Moscow, Nauka Publ., 1989. 608 p.

7. Kationov O.N. Moskovsko-Sibirskiy trakt $i$ ego zhiteli $v X V I I-X I X v v$. [Moscow-Siberian Route and Its Inhabitants in the $17^{\text {th }}-19^{\text {th }} \mathrm{c}$.]. Novosibirsk, Izd-vo NGPU, 2014. $576 \mathrm{p}$.

8. Kosmovskaya A.A. Voevodskoe upravlenie v Permskom Prikamye v kontse XVI-XVII vv.: dis. ... kand. ist. nauk [Voivode Management in the Perm Prikamye in the Late $16^{\text {th }}-17^{\text {th }}$ Centuries. Cand. hist. sci. abs. diss]. Perm, 2015. 254 p.

9. Lappo-Danilevskiy A.S. Organizatsiya pryamogo oblozheniya v Moskovskom gosudarstve so vremen Smuty do epokhi preobrazovaniy [Organization of Direct Taxation in the Moscow State since the Troubles before the Era of Transformation]. Saint Petersburg, Tipografiya I.N. Skorokhodova, 1890. 579 p.

10. Miller G.F. Istoriya Sibiri. V3 t. T. 1 [History of Siberia. In 3 vols. Vol. 1]. Moscow, Leningrad, Izd-vo AN SSSR, 1937.607 p.

11. Nikolaev Yu.K. Bolshaya «gosudareva doroga» v Sibir na uchastke ot Kay-gorodka do Solikamska cherez sela Yukseevo i Kosa [The Big "Monarch Road" to Siberia in the Area from Kai-Gorod to Solikamsk through Yukseevo and Kosa Villages]. Geografiya i turizm: sb. nauch. tr. [Geography and Tourism. Collection of Scientific Papers]. Perm, Izd-vo PGU, 2011, iss. 10, pp. 73-88.

12. Oborin V.A. Zaselenie $i$ osvoenie Urala $v$ kontse XI - nachale XVII vekov [Settlement and Development of the Urals in the Late $11^{\text {th }}$ - the Early $17^{\text {th }}$ c.]. Irkutsk, Izd-vo Irkutskogo universiteta, 1990. $168 \mathrm{p}$.

13. Otpiska vyatskogo voevody $\mathrm{kn}$. M.F. Ukhtomskogo i podyachego Vasiliya Ivanovicha v Perm kn. S.Yu. Vyazemskomu ob otpuske vyatskikh yamshchikov..., 28 dekabrya $1607 \mathrm{~g}$. [Letter from Vyatka Voivode Pr. M.F. Ukhtomsky and Clerk Vasily Ivanovich to Perm to Pr. S.Yu. Vyazemsky on Vyatka Coachmen Leave..., December 28, 1607]. Arkhiv SanktPeterburgskogo instituta istorii Rossiyskoy akademii nauk [Archive of Saint Petersburg Institute of History, RAS], Collection 122, Op. 1, no. 65. 11.

14. Otpiska iz Permi kn. S.Yu. Vyazemskogo v Vyatku voevode kn. M.F. Ukhtomskomu i podyachemu Vasiliyu Ivanovu... ob otpuske iz Soli Kamskoy vyatskikh yamshchikov, 5 yanvarya $1608 \mathrm{~g}$. [Letter from Perm from Pr. S.Yu. Vyazemsky to Vyatka Voivode Pr. M.F Ukhtomsky and Clerk Vasily Ivanov... on the Leave of Vyatka Coachmen from Solikamsk, January 5, 1608]. Arkhiv Sankt-Peterburgskogo instituta istorii Rossiyskoy akademii nauk [Archive of Saint Petersburg Institute of History, Russian Academy of Sciences], Collection 122, Op.1, no. 68. 11.

15. Otpiska iz Permi kn. S.Yu. Vyazemskogo v Vyatku voevode kn. M.F. Ukhtomskomu i podyachemu Vasiliyu Ivanovu o rozyske vyatskikh yamshchikov, bezhavshikh s Solikamskogo yama, do 1 sentyabrya 1607 g. [Letter from Perm Prince. S. Yu. Vyazemsky to Vyatka Voivode Pr. M.F. Ukhtomsky and Clerk Vasily Ivanov on the Investigation for Vyatka Coachmen Fled from Solikamsk Coach Station before September 1, 1607]. Arkhiv Sankt-Peterburgskogo instituta istorii Rossiyskoy akademii nauk [Archive of Saint Petersburg Institute of History, Russian Academy of Sciences], Collection 122, Op. 2, no. 18. 11.

16. Otpiska iz Permi kn. S.Yu. Vyazemskogo i perepisi vyatskim yamshchikam, kotorye imeli loshadey, 4 i 5 sentyabrya 1607 g. [Letter from Perm from Pr. S.Yu. Vyazemsky on the Census to Vyatka 
Coachmen Who Had Horses, September 4 and 5, 1607]. Arkhiv Sankt-Peterburgskogo instituta istorii Rossiyskoy akademii nauk [Archive of Saint Petersburg Institute of History, Russian Academy of Sciences], Collection 122, Op. 2, no. 14. 51.

17. Otpiska iz Permi kn. S.Yu. Vyazemskogo o nevozmozhnosti otpustit iz Soli Kamskoy v Sibir pribyvshikh iz Moskvy detey boyarskikh M. Esipova i S. Burtsova i kazachyego atamana T. Fedorova vsledstvie pobega vyatskikh yamshchikov, May 1607 g. [Letter from Perm from Pr. S.Yu. Vyazemsky on the Impossibility of the Leave of Boyar's Children M. Esipov and S. Burtsov and Cossack Ataman T. Fedorov, Who Arrived from Moscow, from Solikamsk to Siberia Due to the Escape of Vyatka Coachmen, May 1607]. Arkhiv Sankt-Peterburgskogo instituta istorii Rossiyskoy akademii nauk [Archive of Saint Petersburg Institute of History, Russian Academy of Sciences], Collection 122, Op. 2, no. 4.31.

18. Otpiska iz Permi kn. S.Yu. Vyazemskogo o nenakhozhdenii v Soli Kamskoy poruchnykh zapisey po vyatskim yamskim okhotnikam..., do 1 sentyabrya 1607 g. [Letter from Perm from Pr. S.Yu. Vyazemsky on the Failure to Find in Solikamsk Records on Vyatka Coachmen, until September 1, 1607]. Arkhiv SanktPeterburgskogo instituta istorii Rossiyskoy akademii nauk [Archive of Saint Petersburg Institute of History, Russian Academy of Sciences], Collection 122, Op. 2, no. 10. 21.

19. Otpiska iz Permi kn. S.Yu. Vyazemskogo o pobege vyatskikh yamshhikov s Solikamskogo yama, mezhdu 5 sentyabrya i 14 noyabrya $1607 \mathrm{~g}$. [Letter from Perm from Pr. S.Yu. Vyazemsky on the Escape of Vyatka Coachmen from Solikamsk Coach Station, Between September 5 and November 14, 1607]. Arkhiv Sankt-Peterburgskogo instituta istorii Rossiyskoy akademii nauk [Archive of Saint Petersburg Institute of History, Russian Academy of Sciences], Collection 122, Op. 2, no. 15. 11.

20. Otpiska iz Permi kn. S.Yu. Vyazemskogo o poezdke ego v Sol Kamskuyu dlya rassledovaniya zhalob yamskikh okhotnikov na pritesneniya proezzhikh sluzhilykh lyudey..., 6 aprelya 1607 g. [Letter from Perm from Pr. S.Yu. Vyazemsky on His Trip to Solikamsk to Investigate Complaints from Coachmen on the Harassment of Passing Service People, April 6, 1607]. Arkhiv Sankt-Peterburgskogo instituta istorii Rossiyskoy akademii nauk [Archive of Saint Petersburg Institute of History, Russian Academy of Sciences], Collection 122, Op. 2, no. 3. 21.

21. Otpiska iz Permi kn. S.Yu. Vyazemskogo o poluchenii im tsarskoy gramoty s nespravedlivym budto by poritsaniem ego za pritesneniya vatskikh yamshchikov..., posle 4 sentyabrya $1607 \mathrm{~g}$. [Letter from Perm from Pr. S.Yu. Vyazemsky on Receiving a Royal Decree with an Unjust Blaming for Oppressing Vyatka
Coachmen, after September 4, 1607]. Arkhiv SanktPeterburgskogo instituta istorii Rossiyskoy akademii nauk [Archive of Saint Petersburg Institute of History, Russian Academy of Sciences], Collection 122, Op. 2, no. 11.61 .

22. Otpiska iz Permi kn. S.Yu. Vyazemskogo o posylke v Moskvu dlya chelobitya yamskogo okhotnika, prislannogo s Vyatki, Martyna Fedorova, posle 22 fevralya1 $607 \mathrm{~g}$. [Letter from Perm from Pr. S. Yu. Vyazemsky on Sending Coachman Martyn Fedorov, Who was Sent Earlier from Vyatka, to Moscow for a Petition, after February 22, 1607]. Arkhiv SanktPeterburgskogo instituta istorii Rossiyskoy akademii nauk [Archive of Saint Petersburg Institute of History, Russian Academy of Sciences], Collection 122, Op. 2, no. 2. 21 .

23. Otpiska iz Permi kn. S.Yu. Vyazemskogo o posylke v Moskvu poruchnykh zapisey po yamshchikam Solikamskogo yama, posle 4 yanvarya fevral 1607 g. [Letter from Perm from Pr. S. Yu. Vyazemsky on Sending to Moscow Hand-Written Records on Solikamsk Coachmen, after January 4 - February 1607]. Arkhiv Sankt-Peterburgskogo instituta istorii Rossiyskoy akademii nauk [Archive of Saint Petersburg Institute of History, Russian Academy of Sciences], Collection 122, Op. 2, no. 19. 11.

24. Otpiska iz Permi kn. S.Yu. Vyazemskogo o privezennoy $\mathrm{k}$ nemu iz Vyatki tsarskoy gramoty..., 14 iyunya 1607 g. [Letter from Perm from Pr. S.Yu. Vyazemsky on the Royal Decree Brought to him from Vyatka..., 14 June 1607]. Arkhiv SanktPeterburgskogo instituta istorii Rossiyskoy akademii nauk [Archive of Saint Petersburg Institute of History, Russian Academy of Sciences], Collection 122, Op. 2, no. 5.21 .

25. Otpiska iz Permi kn. S. Yu. Vyazemskogo ob otkaze vyatskikh yamshchikov na Solikamskom yame ot otvedennykh im pashen i sennykh pokosov i pobege ikh s yama, 25 dekabrya $1607 \mathrm{~g}$. [Letter from Perm from Pr. S.Yu. Vyazemsky on the Refusal of Vyatka Coachmen in Solikamsk Coach Station from the Arable Lands and Haylands he Provided Them with and Their Escape from Solikamsk, December 25, 1607]. Arkhiv Sankt-Peterburgskogo instituta istorii Rossiyskoy akademii nauk [Archive of Saint Petersburg Institute of History, Russian Academy of Sciences], Collection 122, Op. 2, no. 16. 21. (the beginning); no. 17. 11 . (the end).

26. Otpiska iz Permi kn. S. Yu. Vyazemskogo ob otpuske iz Soli Kamskoy na Verhoturye priekhavshikh iz Moskvy sluzhilykh lyudey..., 10 iyulya $1607 \mathrm{~g}$. [Letter from Perm from Pr. S.Yu. Vyazemsky on the Leave of the Servicemen, Who Came from Moscow, from Solikamsk to Verkhoturye, July 10, 1607]. Arkhiv Sankt-Peterburgskogo instituta istorii Rossiyskoy akademii nauk [Archive of Saint Petersburg Institute 
of History, Russian Academy of Sciences], Collection 122, Op. 2, no. 7. 41.

27. Otpiska iz Permi kn. S.Yu. Vyazemskogo ob otpuske na Verhoturye ostavlennykh sluzhilymi lyudmi v Soli Kamskoy sudokhodnykh zapasov, 9 oktyabrya $1607 \mathrm{~g}$. [Letter from Perm from Pr. S.Yu. Vyazemsky on Delievering from Solikamsk to Verkhoturye Shipping Stores Left by Servicemen, October 9, 1607 Arkhiv Sankt-Peterburgskogo instituta istorii Rossiyskoy akademii nauk [Archive of Saint Petersburg Institute of History, Russian Academy of Sciences], Collection 122, Op. 2, no. 9. 1 1. (beginning); no. 13. 11 . (ending).

28. Otpiska iz Permi kn. S.Yu. Vyazemskogo s prosboyu prislat ukaz o tom, komu nadlezhit chinit mosty na Sibirskoy doroge, 18 avgusta $1607 \mathrm{~g}$. [Letter from Perm from Pr. S.Yu. Vyazemsky with the Request to Send a Decree on Who Should Repair the Bridges on the Siberian Road, August 18, 1607]. Arkhiv SanktPeterburgskogo instituta istorii Rossiyskoy akademii nauk [Archive of Saint Petersburg Institute of History, Russian Academy of Sciences], Collection 122, Op. 2, no. 8. 11 .

29. Otpiska iz Permi kn. S.Yu. Vyazemskogo ob ustroystve Solikamskogo yama i nadelenii zemleyu yamskikh okhotnikov, 22 fevralya $1607 \mathrm{~g}$. [Letter from Perm from Pr. S.Yu. Vyazemsky on Organizing Solikamsk Coach Station and Giving Land to Coachmen, February 22, 1607]. Arkhiv SanktPeterburgskogo instituta istorii Rossiyskoy akademii nauk [Archive of Saint Petersburg Institute of History, Russian Academy of Sciences], Collection 122, Op. 2, no. 1.31 .

30. Pamyat iz Permi kn. S.Yu. Vyazemskogo solikamskomu staroste Ivanu Pyadyshevu... ob otpuske iz Soli Kamskoy vyatskikh yamshchikov..., 5 yanvarya 1608 g. [Report from Perm from Pr. S.Yu. Vyazemsky to Solikamsk Headman Ivan Pyadyshev... on the Leave of Vyatka Coachmen from Solikamsk, January 5, 1608]. Arkhiv Sankt-Peterburgskogo instituta istorii Rossiyskoy akademii nauk [Archive of Saint Petersburg Institute of History, Russian Academy of Sciences], Collection 122, Op. 1, no. 67.11.

31. Rybalko N.V., Dmitrieva E.G. Solikamskiy arkhiv: rekonstruktsiya i istochnikovedcheskiy analiz (1605-1608 gody) [Solikamsk Archive: Reconstruction and Source Studies Analysis (16051608)]. Volgograd, Izd-vo Volgogradskogo gosudarstvennogo universiteta, 2017. $319 \mathrm{p}$.

32. Savenkova N.M. Babinovskaya doroga: novyy vzglyad [Babinovskaya Road: a New Look]. Solikamskiy kraevedcheskiy muzey [Solikamsk Museum of Local History]. URL: http:// skm.solkam.ru/o-muzee/\%D0\%BF\%D1\%83\%
D0\%B1\%D0\%BB\%D0\%B8\%D0\%BA\%D0\%B $0 \% \mathrm{D} 1 \% 86 \% \mathrm{D} 0 \% \mathrm{~B} 8 \% \mathrm{D} 0 \% \mathrm{~B} 8 /$ istoriya-solikamska/ babinovskaya-doroga-novyiy-vzglyad/ (accessed February 28, 2019).

33. Semenov O.V. Vosstanovlenie sistemy regulyarnogo soobshcheniya $\mathrm{v}$ Tyumenskom uezde $\mathrm{v}$ kontse 20-kh gg. XVII v. [Restoration of the Regular Communication System in Tyumen Uezd in the Late Twenties of the $17^{\text {th }}$ c.]. Izvestiya Uralskogo gosudarstvennogo universiteta. Seriya 2, Gumanitarnye nauki, 2010, no. 3 (79), pp. 63-72.

34. Semenov O.V. O vremeni vozniknoveniya sistemy regulyarnogo soobshcheniya $v$ Sibiri [About the Time of Occurrence of the Regular Communication System in Siberia]. Izvestiya Altayskogo gosudarstvennogo universiteta, 2010, no. 4-2 (68), pp. 198-200.

35. Semenov O.V. Stanovlenie i evolyutsiya sistemy mestnogo upravleniya na Urale vo vtoroy polovine $X V$ - pervoy polovine XVII $v$. [Formation and Evolution of the System of Local Government in the Urals in the Late $15^{\text {th }}$ - the Early $\left.17^{\text {th }} \mathrm{c}.\right]$, Ekaterinburg, Bank kulturnoy informatsii, 2006. 292 p.

36. Semenov O.V. Yamskie prikazchiki v Zapadnoy Sibiri v XVII v. [Coachmen Clerks in Western Siberia in the $17^{\text {th }} \mathrm{c}$.]. Gumanitarnye nauki $v$ Sibiri, 2011, no. 1, pp. 7-10.

37. Ukaznaya gramota tsarya V.I. Shuyskogo v Perm Velikuyu kn. S.Yu. Vyazemskomu o bezdenezhnoy dache vyatskim yamskim okhotnikam... dvorov, pashen i sennyh pokosov, 25 marta $1607 \mathrm{~g}$. [The Decree of Tsar V.I. Shuisky to Great Perm to Pr. S.Yu. Vyazemsky on Free Transfer of Courtyards, Arable Lands and Haylands to Vyatka Coachmen], March 25, 1607. Arkhiv Sankt-Peterburgskogo instituta istorii Rossiyskoy akademii nauk [Archive of Saint Petersburg Institute of History, Russian Academy of Sciences], Collection 122, Op. 1, no. 34. 21.

38. Ukaznaya gramota tsarya V.I. Shuyskogo v Perm Velikuyu kn. S.Yu. Vyazemskomu o razverstke yamskoy povinnosti..., 13 sentyabrya $1607 \mathrm{~g}$. [The Decree of Tsar V.I. Shuisky to Great Perm to Pr. S.Yu. Vyazemsky on Organizing Coachmen Duties, September 13, 1607]. Arkhiv SanktPeterburgskogo instituta istorii Rossiyskoy akademii nauk [Archive of Saint Petersburg Institute of History, Russian Academy of Sciences], Collection 122, Op. 1, no. 47.61.

39. Chagin G.N. Na drevney Permskoy zemle [In the Ancient Perm Land]. Moscow, Iskusstvo Publ., 1988. $176 \mathrm{p}$.

40. Semenov O.V. Community Organization of Siberian Coachmen in the Late $16^{\text {th }}-17^{\text {th }}$ Centuries. Bylye Gody, 2014, no. 32 (2), pp. 233-238. (in Russian). 


\section{ИСТОРИЯ СМУТНОГО ВРЕМЕНИ}

\section{Information about the Author}

Natalia V. Rybalko, Candidate of Sciences (History), Associate Professor, Department of National and World History, Archeology, Volgograd State University, Prosp. Universitetsky, 100, 400062 Volgograd, Russian Federation, natalia.rybalko@volsu.ru, rybalko_n@mail.ru, https://orcid.org/0000-0002-5141-0902

\section{Информация об авторе}

Наталия Владимировна Рыбалко, кандидат исторических наук, доцент кафедры отечественной и всеобщей истории, археологии, Волгоградский государственный университет, просп. Университетский, 100, 400062 г. Волгоград, Российская Федерация, natalia.rybalko@volsu.ru, rybalko_n@mail.ru, https://orcid.org/0000-0002-5141-0902 